\title{
ORGANIZATIONAL STRUCTURE OF RELATIONS BETWEEN TECHNICAL HIGHER EDUCATION INSTITUTIONS AND INDUSTRIAL ENTERPRISES AND STUDENTS
}

\author{
Uygun Abdullayevich Urinov
}

Doctor Of Philosophy In Pedagogical Sciences, Bukhara Engineering-Technological Institute, Bukhara City, Republic Of Uzbekistan

\section{ABSTRACT}

The article describes the tasks of cooperation between technical higher education institutions and manufacturing enterprises, as well as students. It was noted that the professional activity of students is formed by performing tasks that require complex skills. Describes the structure of knowledge that students acquire during their studies. The organizational structure of the relationship between higher education institutions and manufacturing enterprises and students is given

KEYWORDS: - Technology, higher education institutions, manufacturing enterprises, students, attitudes, structure..

\section{INTRODUCTION}

In the existing structure of interaction with universities, enterprises are accomplices in the organization of the educational process. On the basis of traditional production tasks, training profiles, topics of course and diploma design are determined. Enterprises take part in the organization of practical training, select applicants for targeted admission to universities. The goal is to improve and model the organizational structure, taking into account the pace of renewal of interests and requirements of the subjects. The organizational structure is developed and used for the formation and management of personnel flows at the stage of personnel training, for tracking changes in human resources, and for the appropriate operation of the flows of information, knowledge, equipment. Since students are not actually potential employees of enterprises, the organizational structure primarily includes the establishment of direct links between students and employers. strategies and dynamics of enterprise development, restructuring of production processes.

\section{THE MAIN PART}

The block-modul system of organizing the educational process allows for the stage-by-stage determination and clarification of the particular goals of the training of each technical specialist 
CURRENT RESEARCH JOURNAL OF PEDAGOGICS 2(12): 49-54, December

2021 DOI: https://doi.org/10.37547/pedagogics-crjp-02-12-11

ISSN 2767-3278

(C)2021 Master Journals

Crossref doi) 81 Google

Accepted 14 th December, 2021 \& Published 19th December, 2021

in accordance with the needs of employers, and design of profiles and individual educational trajectories. This allows us to consider the types and procedure for establishing links between the subjects of the personnel training system, which will ensure the integrity of the system, its identity with the main mission, and the preservation of the main properties during external and internal changes, taking into account the pace of renewal of their interests.

The organization of the final stage of specialized training of specialists allows to transfer the interaction of employers and students from graduation to an earlier stage of training. At the same time, a relatively short period of interaction is highlighted, during which the interests of the subjects can be considered unchanged. This allows us to proceed to the design of functioning mechanisms - the rules and procedures governing the joint activities and actions of each entity: enterprises, students and universities. The goal is to develop a new organizational structure for interaction between enterprises of employers, students and the university, taking into account the pace of renewal of their interests.

The analysis showed that it is rational to develop the organizational structure of interaction on the basis of a block-modular system of organizing the educational process. At the same time, the order of interaction of independent social systems: enterprises, students and universities in the organization of training is considered. In a single, developed, organizational structure of the interaction of independent social systems, the contour of the enterprise and the contour of the university can be distinguished. The selection of these contours allows you to design and systematize the processes of each subject separately. In the future, the organizational structure allows you to move on to the design of principles, methods and mechanisms for managing this activity.
The main goal of interaction between students, employers and universities is the advanced training of technical specialists, and their assignment to the employer. Interaction provides for the formation of individual educational trajectories, taking into account the interests, abilities of students, qualitative and quantitative needs of the labor market.

The structuring of educational programs, provided for by the block-modular system of organizing the educational process, makes it possible to single out the stages of setting and clarifying the particular goals of training each specialist. General scientific training in junior courses makes it possible to unify the educational process for groups of related specialties and areas of training, i.e. form learning streams in areas of training. When moving from stage to stage, the training goals are clarified, and the number of possible trajectories embedded in the educational program is reduced. The variable part of the professional training of a future specialist is formed from the fourth semester of training, the profile of training - from the seventh. This allows you to start interacting with employers not from the first year, but at a later stage of training, and at the same time take into account the abilities and inclinations of students.

The division of the stages of training allows for periodic competitive selection of students for profiles in accordance with the learning outcomes, available resources, the needs of employers, the capabilities of the university. At the same time, an increase in the motivation for training and the competitiveness of the future specialist is ensured. As a criterion for competitive selection, you can enter the success of the interaction between the student and the employer. The assignment of students to the employer is proposed, which, with appropriate regulatory and methodological support, makes it possible to distribute the rights, duties and 
CURRENT RESEARCH JOURNAL OF PEDAGOGICS 2(12): 49-54, December

2021 DOI: https://doi.org/10.37547/pedagogics-crjp-02-12-11

ISSN 2767-3278

(C)2021 Master Journals

Crossref doi) 81 Google

Accepted $14^{\text {th }}$ December, 2021 \& Published $19^{\text {th }}$ December, 2021

responsibilities of the participants in the process for the results of training.

The division of bachelor's training into three stages in a block-modular system does not contradict the current laws and regulations, and does not limit the rights of the student. The organizational stages are fully consistent with the requirements of the Federal State Educational Standard.

The programs for the preparation of masters provide for the continuity and clarification of profiles. Generalized requirements of employers for technical specialists, general training objectives are put in line with each level of professional training. At the level of vocational training, the graduate must know "what to do at a specific workplace"; SPO - "how to do"; higher education - bachelor's degree - "why it is necessary to do this at a specific workplace"; Master's degree - "why it is necessary to do so, taking into account related areas of activity"; doctoral studies - must be able to plan processes for a relatively long period and functionally distribute them.

Teaching in doctoral programs is based on the principle of "education through science". In the modernized block-modul system, this principle is ensured by the competitive selection of talented students and the stage-by-stage involvement of each of them in research activities. The integration of educational levels opens up new potential for doctoral studies as a curriculum. This is the consistency of training with the ability to control and manage, which leads to an increase in the effectiveness of training at this level, as well as the interdisciplinary nature of training and the possibility of organizing network interaction.

Programs at all levels of higher education must ensure the continuity of higher education, they must be consistent across all competencies. Taking into account the pace of updating the qualitative and quantitative needs of the labor market, when organizing the educational process, it is advisable to provide for an adaptive system of joint management of the training of each student.

The formation of educational trajectories in a block-modular system is based on the professional self-determination of students based on the range of proposals presented and the requirements of employers, and on a gradual competitive distribution of students by training profiles. For the effective implementation of this approach, it is necessary to provide for continuous information interaction between the university and enterprises - employers. Relationships at the stage of specialized training of highly qualified technical specialists are fixed by agreements between the university - the employer, the employer - the student.

The design of training profiles is carried out at the expense of the variable part of the educational program and dedicated modules for additional professional training. The use of this approach makes it possible to introduce educational modules into the educational process that are relevant both for the training of students and doctoral students, and for advanced training and retraining of enterprise specialists. Training in additional programs can be carried out at the expense of employers or the students themselves, depending on the target setting of their relationship. This ensures the distribution of the economic responsibility of the parties, and the state becomes not the only guarantor of financial support for training.

The development of the listed activities and connections between the subjects made it possible to develop an organizational structure for the interaction of subjects in a block-modular system of organizing the educational process.

When forming the profiles of master's programs, as well as when distributing students along the 
CURRENT RESEARCH JOURNAL OF PEDAGOGICS 2(12): 49-54, December

2021 DOI: https://doi.org/10.37547/pedagogics-crjp-02-12-11

ISSN 2767-3278

(C)2021 Master Journals

Crossref do: 81 Google

Accepted 14 th December, 2021 \& Published 19th December, 2021

trajectories of training, possible areas of future professional activity are taken into account:

- research, including design and development, experimental activities, as well as theoretical research, modeling, etc.;

- scientific and pedagogical, providing the staff of the university itself.

A characteristic feature of master's programs is scientific work on promising topics of the university, conducting research on its own basis, participating in the work of research groups, and, which is especially important, the organization and management of educational and scientific work of students;

- production activities focused on training a technical specialist for production. Includes design and engineering, design and technology, production, organizational management and other activities.

Distribution according to training profiles is carried out on the basis of agreements between the student and the employer. Moreover, the training of the university's own personnel can be carried out as well. The organization of training highly qualified specialists on the basis of agreements between the student and the employer allows the university to: monitor the most demanded training profiles, involve enterprise specialists in the training process, update and replenish material and technical, information, staffing. Continuous revision of training programs for university teachers and their locations is provided. Contacts are organized in all the main areas of the university's activities.

The educational process is organized in such a way that all participants have the opportunity to put into practice the acquired knowledge and skills, and adapt further training. The structure of the Master's degree program includes:

1. Semester - the development of fundamental professional training (theoretical and practical) with a large share of classroom studies;

2. Semester - a combination of classroom studies and distance learning technologies. It is planned to immerse the trainee in the environment of professional activity, organize practical training and consolidate the acquired skills. The work of a student in a team is positioned in a new way - not the work of a study group of students is considered, but the work of a project group on topics of a real enterprise.

3. Semester - a combination of classroom studies and elements of distance learning, with an increase in the share of distance education. The optional part of the curriculum is mastered, reflecting the profile of training. An active joint participation of teachers and specialists of the enterprise in the educational process is envisaged.

4. Semester - preparation of final qualifying work on the basis of a specialized enterprise with a combination of distance and face-toface consultations of university teachers on the topic of work.

The educational process in the magistracy is based on the use of interactive teaching methods, individual and group work, project teaching methods, work with distributed information sources, practical training and internship with parallel distance theoretical training. Master's educational programs with a block-modular system are based on the principles of continuous interaction, the activity of students and other participants, reliance on experience, and mandatory feedback.

The combination of these approaches contributes to the development of a network form of implementation of doctoral programs in the process of mass training of highly qualified 
CURRENT RESEARCH JOURNAL OF PEDAGOGICS 2(12): 49-54, December

2021 DOI: https://doi.org/10.37547/pedagogics-crjp-02-12-11

ISSN 2767-3278

(C)2021 Master Journals

Crossref do: 81 Google

Accepted 14 th December, 2021 \& Published 19th December, 2021

technical specialists. The structured interaction of the subjects of the system allows the doctoral student and his supervisor to get involved in the real research and production activities of enterprises. Thus, the educational program of doctoral studies becomes a link between the scientific school of the university and enterprises. Studies show that similar processes of replacing the traditional model of training doctoral students with network forms are taking place in Europe.

\section{Results AND discussions}

The organizational structure of training highly qualified personnel reveals multi-level relationships that contribute to the development of the system of higher technical education:

1. The relationship of the content at each level of higher education with the continuity of the training profile. This contributes to the selection and professional adaptation of students.

2. Connections between the university, students and employers, ensuring the allocation of priority training goals and tasks for joint research work.

3. The relationship of students studying at different levels of professional education, contributing to the emergence of project, intercourse and interfaculty groups. For the enterprise, the structure ensures the attraction of the scientific potential of universities to solve real production problems, as well as the earlier attachment of young highly qualified technical specialists to employers. Early professional adaptation, inclusion in real production activities, as well as the possibility of additional earnings are provided for students. For the university, this structure of interaction contributes to the improvement of the qualifications of teachers, the large-scale inclusion of scientific and pedagogical staff in research and development and R\&D, and the attraction of the intellectual, material and technical potential of enterprises to educational and scientific activities.

Thus, a new organizational structure of interaction between enterprises, students and the university is proposed, taking into account the pace of renewal of their interests. The interaction between the student and the employer was transferred from graduation to an earlier stage of the formation of a specialist; it was proposed to assign students to employers. The information environment of interaction contributes to the formation of streams of personnel and knowledge, information, to ensure the choice and organization of educational trajectories at the stages of preparation. Regrouping of students is envisaged during the transition from stage to stage. A competitive interaction environment has been implemented, which ensures the distribution of responsibility of each participant for the result and the formulation of their tasks at each stage. The organizational stages of the educational process are fully consistent with the requirements of the Federal State Educational Standard and do not require changes in legislation.

\section{Conclusion}

In conclusion, the organizational structure of the relationship between enterprises, students and higher education institutions is proposed taking into account the rate of renewal of their interests. The relationship between the student and the employer is left out of the final stage of specialized training. It is proposed to monitor the qualifications of students in stages, which will ensure the formation of the flow of personnel and knowledge. it provides for the appointment of students to the employer, as well as the regrouping of students. A competitive 
CURRENT RESEARCH JOURNAL OF PEDAGOGICS 2(12): 49-54, December

2021 DOI: https://doi.org/10.37547/pedagogics-crjp-02-12-11

ISSN 2767-3278

(C)2021 Master Journals

Crossref dof 81 Google

Accepted 14th December, 2021 \& Published 19th December, 2021

environment has been introduced. At each stage of training and interaction between subjects, their models work, as well as methods of organizing and managing the collaborative process. The simulation results show that a shorter phase of specialized training is more appropriate than recruiting and retraining professionals with work experience or targeted training from the first year.

\section{REFERENCES}

1. U.Sh. Begimkulov, Informatization of pedagogical education: theory and internship (Monography, Tashkent. Fan, 2011)

2. B.S. Nuridinov, U.A. Urinov, Journal of vocational education, 6, 1, 11-16 (2003)

3. K.T. Olimov, International Journal of Innovative Technology and Exploring Engineering 9, 425-429 (2019)

4. U.A. Urinov, European Journal of Research and Reflection in Educational Sciences. Great Britain. Progressive Academic Publishing, 8, 2, 62-65 (2020)

5. U.A. Urinov, ACADEMICIA: An International Multidisciplinary Research Journal, 10, 10, 1321-1328 (2020) 